\title{
Ideologi Keluarga Tradisional "IE" dan Kazoku Kokka pada Masyarakat Jepang Sebelum dan Sesudah Perang Dunia II
}

\author{
Etty N. Anwar
}

\begin{abstract}
In studying Japan's cultural institution, understanding IE, which was the traditional family system used by the Bushi in the Tokugawa era, is indispensable. The IE system is believed to influence the entire aspect of Japanese life, be it the way of thinking, politics, social, economy, marriage, religion, and even the view of "Family State" in the era of Meiji Restoration implemented the structure of IE system. Hence, the IE system is considered to be one of the pillars of Japan's success. This short essay will discuss the IE ideology in the concept of experts on Japanese culture, the principles of Japanese's social relationships, the IE ideology in the structure of "Family State", and Japan's modern family system.
\end{abstract}

KeYWORDS IE, Kazoku Kokka, Shinto, Kaku Kazoku

Seorang pakar sosiologi, Thompson, berpendapat bahwa salah satu sisi, istilah ideologi digunakan oleh beberapa penulis sebagai sebuah istilah yang murni deskriptif: sebagai sistem berpikir, sistem kepercayaan, praktik simbolik yang berhubungan dengan tindakan sosial dan politik. Selalu diasumsikan bahwa ideologi bekerja sebagai perekat hubungan sosial yang mengikat anggota masyarakat secara bersama dengan menerapkan nilai-nilai dan norma-norma yang disepakati secara kolektif (2003: 17-18).

Sementara itu, pakar sosiologi keluarga, Goode mengemukakan bahwa keluarga adalah satu-satunya lembaga sosial-disamping agama-yang secara resmi berkembang di semua masyarakat. Istilah struktur sosial dalam antropologi, seringkali digunakan dalam pengertian struktur keluarga dan kekeluargaan tersebut (1983: 3). Lebih lanjut dijelaskannya bahwa keluarga itu terdiri dari pribadi-pribadi, tetapi merupakan bagian dari jaringan sosial masyarakat yang lebih besar. Hanya melalui keluargalah masyarakat itu dapat memperoleh dukungan yang diperlukan dari pribadi-pribadi warganya 
dan sebaliknya, keluarga hanya dapat terus bertahan jika didukung oleh masyarakat yang lebih luas (Goode 1983: 4).

Pernyataan Goode tersebut di atas diperkuat dengan pendapat Fox yang menyatakan bahwa hubungan kekerabatan dan garis keturunan satu nenek moyang dapat dijadikan titik tolak untuk melacak berbagai interaksi sosial antar warga suatu masyarakat, melacak berbagai hak dan kewajiban serta berbagai loyalitas dan sentimen kemasyarakatan. Bahkan ada masyarakat di mana unsur kekerabatan sangat dipentingkan, loyalitas para warganya terhadap kaum kerabat masing-masing dapat saja menggeser loyalitas lainnya, sehingga pertimbangan atas dasar kerabat sendiri bisa menjadi lawan tangguh bagi birokrasi pemerintahan (1977: 13-14).

Tulisan ini akan membahas tentang ideologi keluarga luas tradisional IE dan Kazoku Kokka (Negara Keluarga) sebelum PD II serta terjadinya perubahan dari sistem IE ke kaku kazoku. Sudah menjadi pengetahuan umum bagi orang Jepang bahwa, sistem keluarga luas tradisional IE adalah suatu sistem keluarga dan kekeluargaan yang berlaku pada zaman Tokugawa (1603-1867) yang utamanya berlaku dikalangan kaum Bushi (Samurai) dan kalangan kaum bangsawan. Namun pada saat Restorasi Meiji (1868), eksistensi sistem IE yang sangat feodal tersebut dikukuhkan dalam Undang-Undang Dasar Meiji yang diberlakukan bagi seluruh lapisan masyarakat Jepang. Bahkan pandangan Negara Keluarga pada zaman Meiji (1868-1912) yang dikenal dengan "Kazoku Kokka" (Negara Keluarga) menerapkan struktur yang terkandung dalam sistem "IE". Namun setelah PD II sistem IE mengalami perubahan menjadi kaku kazoku.

\section{Prinsip-PrinsiP Hubungan Kemasyar aKatan Orang JePANG}

Benedict, seorang pakar antropologi Amerika Serikat dalam salah satu karyanya mengungkapkan bahwa setiap usaha untuk memahami bangsa Jepang harus dimulai dari pengertian mereka tentang apa yang dimaksud dengan seseorang harus mengambil tempat yang sesuai (1982: 50).

Pernyataan bahwa 'seseorang itu harus mengambil tempatnya yang sesuai' di sini adalah bagian yang tidak dapat dipisahkan dari kesadaran dan kepatuhan orang Jepang terhadap sistem hirarki dalam kehidupan warga masyarakat mereka sendiri, maupun dalam kehidupan antarbangsa di dunia. Kesadaran dan kepatuhan orang Jepang terhadap sistem hirarki tersebut sebenarnya berawal dari hasil pembinaan di lingkungan keluarganya masingmasing, seperti yang diungkapkan Ruth Benedict, bahwa setiap orang Jepang mulai mempelajari seluk beluk hirarki di tengah keluarganya. Apa yang dikenal dan dipelajarinya dalam lingkungan keluarganya itu dikemudian hari akan diterapkannya dalam bidang kehidupan ekonomi dan pemerintahan yang lebih luas (Benedict 1982: 62).

Bagi Orang Jepang, tunduk kepada kehendak keluarga dituntut atas nama suatu nilai yang maha tinggi, dalam arti semua anggota keluarga mempunyai kepentingan. Orang Jepang juga belajar dari pengalaman dalam keluarganya, bahwa bobot terbesar yang dapat diberikan kepada suatu keputusan, datang 
dari keyakinan semua anggota keluarga bahwasanya dengan keputusan tersebut kehormatan keluarga mereka akan terjaga. Dan, bila sudah sampai pada keputusan demikian, bagi orang Jepang, bagaimana pun beratnya persyaratan keputusan tersebut harus ditaati oleh semua orang, karena mengatasnamakan loyalitas bersama (Benedict 1982: 62 - 63).

Dalam kaitan dengan loyalitas bersama ini, dilingkungan keluarga luas tradisional IE berlaku prinsip nenkojoretsu dan shushin koyousei. Nenkojo retsu, artinya seseorang harus menempatkan diri sesuai dengan hirarki sempai dan kohai (senior dan yunior). Misalnya. bagi seseorang yang berstatus sebagai jinan (anak laki-laki kedua). Choujo (anak perempuan pertama) dan jijo (anak perempuan kedua) harus memberikan penghormatan terhadap chounan (anak laki-laki pertama) dalam keluarga mereka sesuai dengan apa yang menjadi hak dari chounan, tanpa memperhatikan apakah orang tersebut paling pantas untuk diperlakukan demikian. Sehubungan dengan hal tersebut di dalam keluarga luas tradisional IE dikenal adanya peribahasa 'baka demo chounan', artinya walaupun seseorang itu bodoh, tetapi karena ia anak laki-laki tertua harus dihormati sesuai dengan kedudukannya. Namun walaupun demikian dalam kehidupan keluarga di Jepang, orang tidak diajar untuk menghargai otoritas yang sewenang-wenang dan kebiasaan untuk tunduk pada orang yang sewenang-wenang sama sekali tidak dipupuk. Sementara itu prinsip shushin koyousei mengandung makna kuatnya rasa memiliki serta rasa kesadaran untuk mempertahankan kehormatan keluarga sendiri di mata orang luar.

Bagi orang Jepang, dalam sistem keluarga luas tradisional IE, seseorang dengan kelahirannya sebagai anggota baru pada sebuah keluarga, berarti dia mulai menjalani kehidupannya sebagai bagian dari kesatuan makhluk sosial. Berdasarkan shussei no kankei (hubungan karena kelahiran) itu, orang yang bersangkutan dengan sendirinya menjadi warga suatu masyarakat tertentu. Dengan kehidupan sosialnya sebagai salah satu warga masyarakat itulah, dia diasuh dan dibesarkan oleh keluarganya hingga bisa mandiri, diajar mengenal dan mengembangkan sistem hirarki serta kebudayaan milik masyarakatnya. Selain itu ia secara langsung mendapat status sosial tertentu (ascribed status); misalnya sebagai chounan (anak laki-laki tertua), choujo (anak perempuan tertua), jinan (anak laki-laki kedua), jijo (anak perempuan kedua) sannan (anak laki-laki ketiga), sanjo (anak perempuan ketiga) dan sebagainya.

Di samping itu hubungan kelahiran bagi orang Jepang juga menimbulkan suatu jenis hubungan kekerabatan yang disebut oyako, yakni hubungan antara orang tua dengan anak. Hubungan oyako ini menurut Kyomi, seorang pakar sosiologi Jepang, tidak semata-mata mengatur bagaimana orangtua dan anak-anaknya memainkan peranan yang sesuai dengan status sosial mereka masing-masing dalam sistem hirarki di lingkungan keluarganya melainkan lebih dari itu ia juga berfungsi sebagai prinsip dasar yang menentukan bagaimana setiap warga masyarakat Jepang harus berperan dan bertingkah laku agar sesuai dengan shakaiteki sonzai (eksistensi sosialnya) di masyarakat yang bersangkutan (1967:118). 
Pendapat Mori Oka tersebut di atas nampaknya akan lebih mudah dipahami jika diperjelas dengan pendapat Chie Nakane, seorang pakar antropologi Jepang yang mengemukakan: "Hubungan sosial yang penting dan lazim dalam masyarakat Jepang disebut dengan istilah oyabun-kobun. Oyabun berarti orang yang memiliki status oya (orang tua), sedangkan kobun berarti orang berstatus ko (anak). Dalam kehidupan orang Jepang dewasa ini, seseorang bisa menjadi kobun dari orang lain dan sekaligus menjadi oyabun bagi orang lainnya lagi. Hubungan tradisional oyabun-kobun beralih bentuk menjadi, misalnya, tuan tanah dengan penyewa atau guru dengan murid. Ungkapan-ungkapan itu hingga sekarang masih dipergunakan walaupun secara informal. Istilah oyabun mungkin saja digunakan untuk orang yang paling senior di tempat kerja, menurut orang yang telah lama bekerjasama dengannya dan di antara mereka ada hubungan pribadi yang akrab. Unsur yang paling pokok dalam hubungan demikian ialah bahwa kobun mendapat kan keuntungan atau bantuan dari oyabun-nya, misalnya bantuan untuk mempertahankan pekerjaan, untuk mendapatkan promosi kenaikan pangkat, serta bantuan nasihat pada saat-saat harus membuat keputusan penting. Kobun, sebaliknya harus bersedia membantu oyabun kapan saja diperlukan. Kebanyakan orang Jepang apapun status dan jabatannya, terlibat dalam hubungan oyabun-kobun ini.

Hubungan oyabun-kobun terjadi melalui berbagai kegiatan dan pendidikan yang berkaitan dengan jabatan seseorang dan hal ini menimbulkan implikasi sosial maupun pribadi yang secara simbolis akan tampak dalam masa-masa kritis kehidupan. Tentu saja oyabun memainkan peranan sebagai seorang ayah, sebagaimana diungkapkan dalam istilahnya. Tidaklah sesuatu yang luar biasa di Jepang, bila kemudian ternyata oyabun memainkan peranan yang lebih penting daripada ayah kandung (Nakane 1981:55-56).

\section{Ideologi Keluarga Tradisional "IE" Menurut Konsepsi Beber apa PaKar Ilmu-ILMu Sosial dan Budaya JePANG}

Dalam bahasa Jepang kata IE mempunyai dua arti yaitu IE sebagai bangunan rumah dan IE sebagai suatu sistem limited extended family (keluarga luas terbatas) yang dihitung secara patrilineal. Menurut Chie Nakane, IE dalam arti kedua ini merupakan perwujudan kebudayaan khas Jepang yang tidak ditemukan di negara manapun di dunia (Nakane 1968: i-ii). Sistem IE menurutnya mempengaruhi seluruh aspek kehidupan orang Jepang; kehidupan sehari-hari, perkawinan, cara berpikir bahkan semua aktivitas pekerjaan sangat terikat dan tidak bisa dipisahkan dari struktur IE tersebut. Ditambahkannya IE merupakan sistem keluarga yang terbentuk berdasarkan syarat-syarat ekonomi, tempat tinggal bersama dan atas dasar itu pula dibentuk seikatsu kyodotai, yakni kehidupan bersama.

Senada dengan pendapat Nakane, Kitano juga berpendapat bahwa IE merupakan bentuk keluarga Jepang yang bergerak meliputi berbagai bidang yang saling bertautan fungsi seperti bidang perekonomian, bidang kehidupan 
bersama dan bidang pemujaan terhadap arwah leluhur. Idealnya kehidupan bersama tersebut terdiri dari kumpulan beberapa keluarga inti dengan satu keluarga inti senior yang juga berfungsi sebagai kachou yakni kepala keluarga luas yang disebut $I E$ tersebut. Mereka hidup bersama secara turun-temurun dan berkesinambungan, serta terikat oleh satu garis keturunan yang dihitung secara fukei seido (patrilineal) atau secara giji fukei seido (patrilineal semu). Silsilah nenek moyang suatu keluarga luas IE menurut Kitano, dapat ditelusuri dari kedudukan kachou atau dapat dilihat dari kategorisasi honke (keluarga induk atau keluarga asal) dan bunke atau keluarga cabang (1973: 140).

Sehubungan dengan pendapat Kitano mengenai kachou, seorang ahli filsafat Jepang, Ino Ue Tetsujiro, bahkan berpendapat bahwa konsep IE harus dipahami dari ciri-ciri khasnya yang membedakannya dengan konsep keluarga pada masyarakat Barat, yaitu: (a) harus adanya seseorang yang menjadi kachou (kepala keluarga) sebagai wakil leluhur untuk memimpin keluarga luas IE yang bersangkutan; (b) harus adanya ketaatan untuk menghormati kachou dan (c) adanya kesinambungan sejarah keluarga dari masa lampau hingga ke masa kini (Ienaga 1978: 8).

Melengkapi pendapat di atas, Torigoe Hiroyuki mengemukakan bahwa, IE merupakan suatu unit dasar bagi kehidupan orang Jepang yang mempunyai tiga ciri khas, yaitu: (a) mempunyai zaisan, yakni harta-benda sebagai warisan dan berdasarkan harta warisan itu diselenggarakan suatu aktivitas kehidupan bersama yang berkaitan dengan perekonomian bersama, (b) sosen suuhai, yakni secara periodik menyelenggarakan upacara pemujaan terhadap arwah leluhur $I E$, dan (c) melestarikan myoji yakni mengutamakan kesinambungan nama keluarga dan meneruskan kelangsungan keturunan dari generasi ke generasi berikutnya.

Tradisi untuk meneruskan nama keluarga bagi orang Jepang, sebenarnya berkaitan erat dengan tradisi sosen suuhai (pemujaan terhadap arwah leluhur). Sehubungan dengan tradisi ini, seorang ahli budaya Jepang, Takeda Chosu, mengemukakan bahwa sosen suuhai bagi orang Jepang merupakan suatu kewajiban moral seseorang terhadap para leluhurnya,yang dilakukan secara individu maupun secara berkelompok. Menurutnya, kelompok keluarga luas IE adalah wadah yang dapat menjamin kesinambungan bagi penyelenggaraan pemujaan terhadap leluhur tersebut. Oleh karena itu yang dinamakan IE harus berlanjut terus dan tidak boleh berhenti hanya disebabkan kachou tidak mempunyai anak laki-laki sebagai pewaris atau bahkan tidak mempunyai 'keturunan darah'. Bila terjadi kasus semacam ini, penerus $I E$ dapat dilimpahkan kepada salah seorang anggota keluarga atau kerabat yang bukan keturunan langsung dari kachou, misalnya keponakan atau keturunan fiktif seperti anak angkat (yoshi). Selain itu menurut Chosu, penerus IE bisa juga diambil alih oleh istri kachou yang meninggal dunia, atau dapat pula diteruskan oleh shiyounin (abdi dalem) yang mempunyai kesadaran rasa memiliki IE tersebut dan merasa berkewajiban meneruskan kesinambungan nama keluarga majikannya (1978: 13-20). 
Sementara itu, Aruga, seorang pakar sosiologi pedesaan, berpendapat bahwa IE merupakan seikatsu shuudan (kelompok kehidupan) atau seikatsu kyoudotai (satuan kehidupan bersama), yang melakukan aktivitas dalam pengelolaan usaha keluarga dan warisan keluarga. IE akan berlangsung terus-menerus meskipun keanggotaannya selalu mengalami pergantian dari masa kemasa. Status dari anggota pembentuk $I E$ walaupun berpangkal dari adanya ikatan suami-istri, namun bukanlah semata-mata berdasarkan garis keturunan darah, melainkan dapat pula ditentukan oleh hubungan yang bersifat keagamaan seperti sosen suuhai (pemujaan leluhur), hubungan ekonomi, hukum, moral, budaya dan sebagainya. Ditegaskan oleh Aruga, $I E$ dapat terbentuk tidak hanya oleh penerus utama (biasanya chounan atau anak laki-laki tertua) tetapi juga bisa terbentuk oleh kaum kerabat yang bukan penerus utama yang disebut boukei, seperti jinan (anak laki-laki kedua), sannan (anak laki-laki ketiga). Bahkan orang yang bukan keturunan langsung punseperti yoshi (anak angkat), mukoyoshi (menantu penerus nama keluarga), dan para meshitsukai (pembantu keluarga) - bisa saja meneruskan kesinambungan IE asalkan mereka mempunyai kazoku ishiki (kesadaran keluarga) dalam arti memiliki loyalitas yang tinggi terhadap eksistensi IE tersebut sebagai satuan kehidupan bersama. Menurut Aruga ada tidaknya kesadaran dan rasa memiliki dari anggota IE terhadap eksistensi dan tata tertib keluarga dinilai sangat penting oleh orang Jepang. Kesadaran semacam ini merupakan kesadaran terhadap kehidupan bersama serta semangat dan kemauan untuk mempertahankan, mengembangkan dan melestarikan kesinambungan IE itu sebagai suatu kelompok kehidupan bersama.

Di sisi lain, seorang ahli sosiologi pedesaan Jepang, Fukutake, berpendapat bahwa sejak zaman Tokugawa sampai berakhirnya Perang Dunia II, kazoku seido (sistem keluarga) yang berlaku dalam masyarakat Jepang diatur oleh konsepsi tentang IE yang mengikuti cita-cita kaum bushi (samurai) dan bahkan mendapat pengakuan secara hukum dalam Hukum Sipil Meiji (1988: 37). Dalam hukum tersebut antara lain dinyatakan:

a. Bagi setiap anggota keluarga, kepentingan IE harus mendapat prioritas utama daripada kepentingan pribadi.

b. Kachou (kepala keluarga IE) mempunyai wewenang yang besar menyangkut berbagai aspek penting dalam kehidupan keluarga, termasuk aspek perekonomian keluarga, hak waris, dan pemujaan terhadap arwah leluhur.

c. Prinsip hubungan oyako (hubungan bapak dan anak) lebih dijunjung tinggi daripada hubungan suami-istri.

d. Chounan (anak laki-laki tertua) mempunyai hak sebagai pewaris utama untuk menduduki jabatan kachou, serta hak-hak lainnya yang lebih penting dari anak laki-laki kedua dan seterusnya.

e. Harkat dan martabat laki-laki lebih diutamakan dari wanita.

f. Perkawinan lebih diutamakan sebagai penyatuan dua kelompok kekuarga IE daripada penyatuan individu suami-istri. 
g. Martabat honke (keluarga induk atau keluarga asal) lebih diutamakan dari bunke atau keluarga cabang (Kazuo 1974: 5-6).

\section{Ideologi Keluarga Tradisional "IE" dalam struktur Kazoku KOKKA}

Sebagaimana telah disinggung sebelumnya bahwa sistem keluarga tradisional " $I E$ " yang telah berlangsung lebih kurang dua ratus lima puluh tahun lamanya diberlakukan pada zaman Tokugawa (1603-1867), boleh dikatakan telah menjadi salah satu pilar kekuatan bangsa Jepang di zaman pra modern. Sistem yang berlaku di kalangan kaum Bushi ini tentunya sangat dipengaruhi oleh etika moral kaum Bushi atau cara hidup kesatria militer yang dikenal dengan istilah Bushido yang di dalamnya terkandung tiga ajaran yang sangat dominan turut membentuk kepribadian bangsa Jepang yakni Budhisme, Shintoisme, dan Konfusianisme. Dengan etika moral Bushido dan sistem IE yang berideologikan ajaran Konfusianisme dan Shintoisme, pemerintah Tokugawa telah menciptakan masa damai yang cukup panjang. Sistem IE bukan suatu keluarga yang hanya ada pada suatu waktu tertentu tetapi keberadaannya dari masa lalu, masa kini dan masa yang akan datang dan sangat menekankan shinwasei (sifat persaudaraan) dan keberlangsungan yang terus menerus. Sistem yang utamanya menjadi anutan kaum Bushi (samurai) dan kaum bangsawan, pada saat Restorasi Meiji (1868) eksistensinya diberlakukan untuk seluruh lapisan masyarakat (petani, pengrajin, pedagang dan sebagainya) yang disahkan dalam Undang-Undang Dasar Meiji. Bahkan menurut Ino Ue Tetsujiro seorang ahli filsafat Jepang, lahirnya konsep Negara Keluarga yang disebut Kazoku Kokka atau Kokutai (bentuk pemerintahan nasional), yang mengukuhkan pengabdian rakyat terhadap Tenno (kaisar) sebagai kachou (kepala keluarga) dari keluarga besar yang meliputi seluruh bangsa Jepang, sebenarnya mengambil gagasan dari konsep keluarga luas tradisional IE. Sehubungan dengan konsep Kazoku Kokka (Negara keluarga) yang didukung oleh konsep Kokka Shinto (Shinto Negara), yang sangat popular pada zaman Meiji sampai berakhirnya Perang Dunia II, Tetsujiro menjelaskan:

Sistem Negara Jepang adalah kachou seido (sistem kepala keluarga), yang menempatkan Tenno (kaisar) sebagai kachou (kepala keluarga). Tenno dianggap sebagai simbol oya (orang tua) dari seluruh rakyat Jepang yang dianggap sebagai ko (anak). Karena rakyat biasa tidak bisa bertemu dengan Kaisar, maka bila dalam kehidupan sehari-hari seseorang mentaati dan berbakti pada kachou di lingkungan IE-nya masing-masing dengan baik, dengan penuh kejujuran melaksanakan tugas serta mencurahkan kesetiaannya sepenuh hati, berarti orang yang bersangkutan telah mengabdi, berbakti dan mencurahkan kesetiaan pada Kaisar. Dengan kata lain bila seseorang dengan sepenuh hati berbakti dan mengabdi pada orang tuanya sama halnya seperti mencurahkan kesetiaan pada Kaisar. Di Jepang pengabdian dan kesetiaan merupakan suatu prinsip (Saburo 1978: 8-10). 
Dengan demikian apa yang dimaksud dengan Kazoku Kokka (Negara Keluarga), adalah suatu sistem pemikiran yang memahami eksistensi kunmin yakni penguasa (dalam konteks ini Kaisar) dengan rakyat, seperti hubungan oyako (bapak dan anak) dalam hubungan keluarga. Kaisar dikukuhkan sebagai pucuk pimpinan dalam Kazoku Kokka atau Negara keluarga. Kaisar dianggap sebagai keturunan dari Amaterasu Omikami yakni Dewa Matahari, oleh karena itu segala perintahnya dianggap mutlak. Perwujudan kesetiaan terhada kaisar, siap berkorban nyawa demi kaisar dan menjunjung tinggi kaisar di atas segalanya merupakan manifestasi nasionalisme Jepang. Keadaan ini sesuai dengan semangat zaman yang menuntut masyarakat untuk berjuang keras dalam menghadapi ancaman Barat serta mengejar ketertinggalan dari teknologi Barat.

Pandangan bangsa Jepang terhadap Kaisar sebagai simbol pemersatu bangsa yang harus dijunjung tinggi, sesungguhnya telah berlangsung sejak zaman Kuna Jepang, sebagaimana tercermin dalam pasal keduabelas Jushichijo no Kenpo (Undang-Undang Tujuh belas Pasal) yang dibuat oleh Pangeran Shotoku Taishi pada tahun $604 \mathrm{M}$, dengan mengambil pola pemikiran ajaran Konfusianisme Cina yang berbunyi:

\footnotetext{
"Kaisar adalah langit, hamba adalah bumi, langit menyelubung dan bumi mendukungnya. Apabila bumi hendak menggulingkan langit, maka tujuannya tidak akan tercapai. Negara tidak mempunyai dua kepala, begitu pula rakyat tidak mempunyai dua tuan. Rakyat diseluruh Negeri adalah anak buah Kaisar" (Inoue 1974: 240).
}

Sementara itu Nitobe dalam bukunya Bushido menjelaskan:"Bagi bangsa Jepang Kaisar adalah lebih dari seorang politikus kawakan dalam suatu Negara Hukum atau bahkan Pelindung suatu Negara Budaya. Ia dianggap sebagai wakil berbadan jasmani dari sorga di dunia yang memadukan kepribadiannya, kekuasaan dan belas kasihnya - kaisar bukan hanya gambaran kekuasaan, tetapi sumber dari lambang kesatuan nasional (1992: 12 - 13).

Pemikiran Kazoku Kokka atau Kokutai pada dasarnya juga merupakan prinsip pemikiran yang memadukan prinsip kekeluargaan, politik dan keagamaan, di mana agama Shinto yang ajarannya bersifat sekuler dan berori entasi pada kekuatan mistik dikukuhkan sebagai Kokka Shinto (Shinto Negara) dan Kaisar berperan sebagai pemimpin keagamaan yang harus dihormati dan dijunjung tinggi. Shinto mengajarkan pada penganutnya untuk percaya pada banyak dewa dan secara hirarkis dalam sistem kepercayaan ini Amaterasu Omi kami (Dewa Matahari) dianggap sebagai dewa tertinggi. Oleh karena itu Shinto dapat dikatakan sebagai mitos ideologis untuk memperkuat otoritas pemerintahan yang dilaksanakan oleh kaisar, yang dianggap sebagai keturunan Amaterasu Omikami atau Dewa Matahari. Namun demikian ideologi Kazoku Kokka ini hancur seiring dengan kekalahan Jepang dalam Perang Dunia II.

Sejalan dengan proses pekembangan masyarakat Jepang modern terutama setelah Perang Dunia II, sisterm keluarga tradisional IE pun perlahan-lahan telah ditinggalkan oleh generasi muda Jepang yang cenderung lebih menyukai 
sistem keluarga modern yang bertumpu pada sistem keluarga inti atau keluarga batih yang disebut kaku kazoku.

\section{Sistem Keluarga Modern KaKu KazoKu}

Menurut ahli sosiologi Jepang, Fukutake, istilah kaku kazoku (nuclear family) menjadi biasa digunakan orang sebagai istilah sosiologi setelah terbitnya buku Social Structure karangan G.P Murdock pada tahun 1949. Akan tetapi, sampai dengan sekitar tahun 1960 di dunia ilmu pengetahuan di Jepang belum ada istilah yang baku untuk terjemahan istilah nuclear family. Istilah kaku kazoku baru dalam satu dua dasawarsa terakhir ini menjadi bagian kosakata bahasa Jepang, dan telah umum digunakan sebagai terjemahan istilah nuclear family tersebut. Hal ini menurut Fukutake dapat dijadikan saksi bagi cepatnya perubahan dalam struktur keluarga Jepang (1988: 40).

Seorang pakar sosiologi Matsubara bahkan berpendapat bahwa, kaku kazoku adalah sistem keluarga yang semakin popular dalam masyarakat Jepang, sebagai pengganti sistem IE. Menurutnya ada tiga faktor utama yang menyebabkan sistem IE tergeser oleh sistem kaku kazoku, yaitu: (1) Hilangnya landasan hukum tahun 1946, serta adanya perubahan dalam Hukum Sipil tentang Keluarga dan Warisan pada tahun 1948; (2) Tumbuhnya pemikiran tentang demokrasi pada berbagai lapisan masyarakat setelah Perang Dunia II melalui sistem pendidikan modern yang merata di seluruh Jepang, sehingga membentuk pendapat umum yang menganggap sistem IE kurang demokratis, dan (3) Adanya perubahan drastis dalam pola kehidupan keluarga di Jepang setelah tahun 1955 ke atas (1983: 34).

Akan tetapi, seorang ahli sejarah Jepang, Hikaru berpendapat bahwa gejala timbulnya sistem kaku kazoku telah ada sejak masa Restorasi Meiji, yaitu dengan munculnya gejala kengyonoka (buruh pabrik musiman) dan gejala dekasegi (urbanisasi musiman) di lingkungan keluarga petani Jepang pada masa itu (1979:210). Dengan berkembangnya kengyonoka dan dekasegi di Jepang sejak masa Restorasi Meiji itu memberi kemungkinan kepada para anggota keluarga petani untuk tidak terlalu terikat dan terlibat dalam kegiatan pertanian yang telah dilakukan keluarganya secara turun-temurun. Adanya kenyataan ini, lambat laun mengakibatkan hilangnya keharusan bagi seorang chounan (anak laki-laki tertua) untuk meneruskan atau mewarisi pekerjaan ayahnya di bidang pertanian, sehingga mengakibatkan goyahnya salah satu sendi dari sistem $I E$, terutama hilangnya fungsi aktivitas perekonomian keluarga.

Apabila bagi chounan saja yang harus menjadi kachou IE sudah terbuka untuk mencari lapangan pekerjaan lain di luar pekerjaan yang ditekuni nenek-moyangnya, maka sudah barang tentu bagi jinan, sannan, dan lainnya kemungkinan untuk memperoleh pekerjaan lain, misalnya bekerja di sektor industri, semakin terbuka lebar. Mereka yang sebelumnya secara tidak langsung mempunyai kewajiban untuk membantu chounan dalam meneruskan pekerjaan keluarga yang diwarisi dari orang tua mereka, kini seolah-olah mendapat suatu justifikasi (dasar pembenaran) untuk melupakan kewajiban 
semacam itu. Lama kelamaan sejalan dengan proses industrialisasi dan modernisasi Jepang, semakin banyak keturunan para petani yang melakukan kerja sambilan di pabrik-pabrik dan melakukan urbanisasi musiman itu yang kemudian benar-benar pindah ke kota-kota dan berganti pekerjaan dari petani menjadi karyawan pabrik sepenuhnya.

Dari uraian di atas, kiranya beralasan bila Hikaru berpendapat bahwa berkembangnya gejala kengyonoka dan dekasegi pada masa Restorasi Meiji itu secara tidak langsung dapat dianggap sebagai salah satu penyebab yang merangsang banyak orang Jepang untuk lebih mementingkan kaku kazoku daripada IE (1979: 211)

Di sisi lain, menurut Matsubara terjadi perubahan drastis dalam jumlah anggota keluarga di masyarakat Jepang sesudah Perang Dunia II. Matsubara mengemukakan, kalau di antara tahun 1920 sampai dengan 1955 jumlah anggota keluarga rata-rata 5 (lima) orang perkeluarga, maka antara tahun 1956 sampai dengan 1964 angka rata-rata perkeluarga menyusut menjadi 4 (empat) orang. Dengan demikian, jika pada tahun 1955 ke bawah banyak dijumpai keluarga dengan 8 (delapan) orang anggota (yaitu: kakek, nenek, ayah, ibu dan empat orang anak), maka pada tahun 1955 ke atas lebih banyak dijumpai keluarga Jepang dengan 4 (empat) orang anggota (ayah, ibu dan dua orang anak). Jumlah rata-rata anggota per keluarga ini semakin tahun semakin menyusut, dan berdasarkan sensus penduduk tahun 1982 jumlah rata-rata anggota keluarga tinggal 3,20 perkeluarga.

Sementara Fukutake memperinci penyusutan jumlah anggota rata-rata per keluarga Jepang sebagai berikut: Pada ahun 1955 rata-rata keluarga mempunyai 4,97 anggota, kira-kira sama seperti sebelum PD II. Tahun 1960 jumlah itu menurun jumlah menjadi 4,54 dan menjelang tahun 1965 menjadi 4,05. Menurut sensus penduduk tahun 1970, jumlah rata-rata ini menyusut lagi di bawah 4 sampai 3,69 per keluarga. Bahkan pada sensus tahun 1980 jumlah anggota perkeluarga Jepang rata-rata 3,3. Seterusnya menjelang tahun 1985, menurut perhitungan Fukutake, jumlah rata-rata anggota keluarga Jepang tinggal menjadi 3,1 per keluarga (1988: 38). Tahun 2007 sekarang ini sudah dapat diperkirakan bahwa angka tersebut turun lagi. Fenomena terus-menerus menurunnya kelahiran anak di Jepang ini, sejak tahun tahun 1990-an dikenal dengan istilah shoushika.

Terjadinya proses perubahan dalam struktur keluarga di Jepang dari sistem IE ke kaku kazoku, tentunya membawa dampak positif dan negatif. Dampak positifnya antara lain: (a) hak setiap individu di dalam keluarga lebih dihormati; (b). istri mempunyai hak bersama suami mengatur bahtera rumah tangganya sendiri tanpa campur tangan mertua; (c) anak laki-laki dan anak perempuan mempunyai persamaan hak untuk menerima warisan dari orang tuanya. Sebaliknya, dampak negatif antara lain: (a) kehidupan kaum lanjut usia semakin kurang terjamin sedangkan beban Negara untuk mengatasi masalah ini semakin besar; (b) proses sosialisasi nilai-nilai yang mementingkan faktor hirarki dalam keluarga dan dalam masyarakat mulai terganggu dan hal ini sedikit demi sedikit akan mempengaruhi karakter 
orang Jepang dimasa-masa mendatang. Pendek kata, keluarga Jepang zaman sekarang belum berhasil menciptakan landasan untuk membentuk perwatakan pribadi Jepang yang baru.

Namun demikian, bagi bangsa Jepang yang dalam segala hal terkenal dengan kemampuannya untuk mengadaptasi setiap pengaruh dan gelombang perubahan tanpa kehilangan jati dirinya itu, unsur-unsur positif dari sistem keluarga luas tradisional IE tidak mereka buang begitu saja. Bahkan menurut Nakane, secara substansial nilai-nilai positif itu telah merasuk ke dalam institusi pemerintah maupun swasta di masyarakat Jepang dewasa ini. Meskipun sering dikatakan lembaga keluarga tradisional IE lenyap, namun konsep IE masih tetap bertahan dalam masyarakat Jepang modern. Suatu perusahaan di Jepang, oleh seluruh karyawannya dianggap sebagai IE. Semua pekerjanya dinilai sebagai anggota keluarga, sedangkan majikan menjadi kachou (kepala keluarga). Keluarga besar perusahaan ini mencakup anggota keluarga dari setiap karyawannya, serta mengikat mereka dalam suatu marugakae (ikatan kekeluargaan sepenuhnya). Menurut Nakane, analisa ini menuntut penimbangan ulang atas pandangan stereotipe bahwa modernisasi atau urbanisasi memperlemah ikatan kekeluargaan serta menciptakan suatu organisasi sosial tipe baru atas berbagai dasar yang sama sekali berbeda. Tentu saja indutrialisasi menghasilkan suatu organisasi tipe baru yang struktur formalnya mungkin sama dengan yang terdapat dalam masyarakat Barat modern. Tetapi, hal ini tidak harus berarti mengubah struktur informal yang sebagian besar mempertahankan struktur tradisional, seperti yang kita lihat dalam kasus Jepang ini (1981: 4 - 5).

\section{PENUTUP}

Jika kenyataan di masyarakat Jepang sebagaimana diuraikan melalui kutipan pendapat Nakane di atas dikaitkan dengan semakin populerrnya sistem kaku kazoku pada kalangan generasi muda Jepang sekarang, dapat diramalkan bahwa dalam beberapa dasawarsa mendatang akan terjadi perubahan bahkan krisis nilai di perusahaan-perusahaan Jepang yang mengambil alih prinsip-prinsip hubungan dalam sistem IE. Hal ini dilandasi oleh asumsi bahwa dalam kenyataan, sistem keluarga modern yang lebih bertumpu pada sistem keluarga inti di masyarakat Jepang sekarang, tidak sepenuhnya mampu melaksanakan fungsi pendidikan seperti pada keluarga tradisional $I E$, terutama dalam segi pendidikan yang berkaitan dengan pengetahuan dan ketaatan seseorang terhadap hirarki dan disiplin yang lebih mengutamakan kepentingan kelompok daripada kepentingan pribadi.

Apa yang telah dikemukakan secara menarik oleh Benedict - sebagaimana dikutip pada sub bab terdahulu, bahwa setiap orang Jepang mulai mempelajari seluk beluk hirarki di tengah keluarganya sebagai modal dasar untuk kemudian hari diterapkannya dalam lingkungan masyarakat yang lebih luas, sesungguhnya hanya terjadi dalam pola pendidikan di lingkungan keluarga luas tradisional IE, bukan pada keluarga modern kaku kazoku. 
Dalam masyarakat Jepang dewasa ini sedang terjadi perubahan-perubahan drastis dalam sistem dan struktur keluarga, Sistem keluarga luas tradisional IE semakin ditinggalkan dan sistem keluarga modern kaku kazoku semakin populer. Namun dampak dari perubahan ini yang sangat memprihatinkan adalah munculnya fenomena shoushika (menurunnya angka kelahiran anak). Bagaimana Jepang di masa yang akan datang bila generasi muda berkurang sedangkan generasi tua semakin meningkat. Pandangan masyarakat Jepang terhadap anak, bukan lagi sebagai suatu nilai produktif seperti halnya dalam sistem keluarga tradisional IE tetapi telah berubah menjadi nilai konsumtif, karena rasio untuk membesarkan dan mendidik anak membutuhkan biaya yang tidak sedikit. Fenomena shoushika ini tentunya akan sangat berpengaruh terhadap sistem perekonomian Jepang, karena generasi penabung dan pekerja akan semakin berkurang, sementara generasi tua yang harus ditanggung dan diperhatikan pemerintah semakin bertambah. Bila tidak diantisipasi dan diatasi Jepang akan mengalami suatu masa yang penduduknya mayoritas generasi tua.

\section{DAFTAR ACUAN}

Aruga, Kizaemon. 1986. “Dozoku to Shinzoku” (Dozoku dan Shinzoku), terhimpun dalam Mitsuyosi, dkk. Dento Kazoku (Keluarga Tradisional). Tokyo: Tokyo Daigaku Shuppankai.

Benedict, Ruth. 1982. Pedang Samurai dan Bunga Seruni: Pola-pola Kebudayaan Jepang. Diterjemahkan oleh Pamuji. Jakarta: Sinar Harapan.

Chosu, Takeda. 1978. Sosen Suuhai (Pemuja Leluhur). Heirakuji Shoten.

Fukutake, Tadashi. 1988. Masyarakat Jepang Dewasa Ini. Diterjemahkan oleh Haryono. Jakarta: Yayasan Kartika Sarana bekerja sama dengan PT Gramedia.

Goode, William J. 1983. Sosiologi Keluarga. Diterjemahkan Oleh Lailahanoem Hasyim Jakarta: PT Bina Aksara.

Hikaru, Furuta. 1978. Kindai Nihonshi (Sejarah Jepang Zaman Modern). Tokyo Kabunori Kaisyu.

Hiroyuki, Torigoe. 1985. IE to Mura no Shakaigaku (Sosiologi Desa dan IE). Shakai Shisoosya.

Nitobe, Inazo.1992. Bushido-Kepribadian bangsa Jepang, Suatu Ulasan Tentang Alam Pikiran Jepang. Diterjemahkan oleh Haryono. Semarang, Yayasan Karti Sarana

Ienaga, Saburo. 1978. "Nihon no IE Kannen (Konsep IE Jepang)”, dalam Aoyama dkk., Kazoku (Keluarga). Tokyo: Kabushiki Gaisya.

Inoue, Mahikari. 1974. Nihon no Rekishi (Sejarah Jepang). Tokyo, Dainihoninkaisha.

Kitano, Seiichi. 1973. Sonroku Kozo to Shinzoku Shoshiki (Struktur Desa dan Sistem Shinzoku). Tokyo: Miraisha

Kazuo, Aoi. 1974. Kazoku to wa Nanika (Apa Yang Dinamakan Keluarga). Tokyo: Kabushiki Geisya Kodansya.

Kyomi, Mori Oka. 1967. Kazoku Shakaigaku (Sosiologi Keluarga). Yuhikaku Shoosho.

Matsubara, Haruo. 1983. "Genzai no Kazoku”, dalam Chie Nakane, IE. Tokyo: Tokyo Daigaku. Hlm. 29-65.

Nakane, Chie. 1968. Kazoku no Kozo (Struktur Keluarga). Tokyo: Tokyo daigaku Shuppankai. 1977. Tate Shakai ni Ningen Kankei: Tan Itsu Shakai Bon (Hubungan Masyarakat Vertikal : Argumentasi Masyrakat Homogen). Tokyo, Kodansya Gendai.

. 1981. Masyarakat Jepang. Diterjemahkan oleh Bambang Kussriyanto dan Biro Terjemah Satya Karya. Jakarta: Sinar Harapan.

Thompson, John B. 2003. Analisis Ideologi, Kritik Wacana Ideologi Dunia. Diterjemahkan oleh Haqqul Yaqin. Yogjakarta: IRCiSod. 